\title{
Hivenaineet ja kestävä tehostaminen
}

\author{
Mervi M. Seppänen ${ }^{1)}$, Anthony Owusu-Sekuyere ${ }^{1)}$, Elina Keski-Soini ${ }^{2)}$, Markku Yli-Halla ${ }^{3)}$, Jarmo Valaja ${ }^{1)}$, \\ Matthias Stamm ${ }^{1)}$, Anni Halmemies-Beauchet-Filleau ${ }^{1)}$, Seija Jaakkola ${ }^{1)}$ \\ ${ }^{1)}$ Maataloustieteiden laitos, PL 27, 00014 Helsingin yliopisto. mervi.seppanen@ helsinki.fi, \\ owususek@mappi.helsinki.fi,jarmo.valaja@helsinki.fi,matthias.stamm@helsinki.fi, \\ anni.halmemies@helsinki.fi,seija.jaakkola@helsinki.fi \\ 2) ProAgria Pohjois-Karjala, PL 5, 80101 Joensuu.elina.keski-soini@ proagria.fi \\ 3) Elintarvike- ja ympäristötieteiden laitos, PL 27,00014 Helsingin yliopisto. markku.yli-halla@helsinki.fi
}

\section{TIIVISTELMÄ}

Hivenainekoostumus on yksi tärkeimpiä ruoan ja rehujen ravitsemuksellisen laadun mittareita. Ihmisten ja tuotantoeläinten dieetti voi olla energian saannin kannalta riittävä, mutta siitä voi puuttua elintärkeitä hivenaineita, mikä aiheuttaa niin sanotun piilonälän (hidden hunger) ja sen seurauksena puutoksesta johtuvaa kasvun ja kehityksen hidastumista tai sairauksia. Hivenaineita voi olla myös yli ihmisen ja eläinten fysiologisen tarpeen, vaikka varsinaista haitallisen runsasta saantia esiintyy harvoin. Ruoan ja rehujen hivenainepitoisuuteen vaikuttavat ensisijaisesti ravinteen saatavuus maasta sekä hivenaineita sisältävät lannoitteet. Tässä tutkimuksessa selvitettiin, miten kestävä tehostaminen ja tavoite valkuaisomavaraisuuden lisäämisestä voivat vaikuttaa ihmisten ja eläinten hivenaineiden saantiin. Sikojen, siipikarjan ja lypsylehmien hivenaineiden laskennallista saantia tarkasteltiin ilman kivennäistäydennystä erilaisilla malliruokinnoilla, joissa soija- tai rypsirouhetta korvattiin palkoviljoilla. Lisäksi laskettiin nurmisäilörehun puna-apilapitoisuuden lisäämisen vaikutukset lypsylehmän hivenaineiden saantiin. Kasvihuonekokeissa tutkittiin orgaanisen lannoitteen sisältämien hivenaineiden käyttökelpoisuutta viljelykasveille ja miten siemensato muuttuu korvattaessa $50 \%$ mineraalitypestä sian lietelannan typellä. Lisäksi selvitettiin härkäpavun, valkolupiinin ja vehnän eroja hivenaineiden oton tehokkuudessa.

Rehutaulukoiden ja kirjallisuuden mukaan palkokasvien siementen ja soija- ja rypsirouheen hivenainepitoisuuksien erot vaihtelevat riippuen kasvilajista ja hivenaineesta. Esimerkiksi palkokasvien siementen rauta- ja mangaanipitoisuudet ovat pienempiä kuin soija- ja rypsirouheen, mutta sinkkipitoisuuksissa erot ovat melko pieniä. Hivenaineiden pitoisuuserot eivät johtaneet oleellisiin eroihin laskettaessa eläinten hivenaineiden saanteja. Erityisesti yksimahaisten ruokintamalleissa perusrehuista saadut hivenainetasot olivat selvästi alle kotimaisten ruokintasuositusten, ja käytännössä täydennys on tarpeen. Nurmipalkokasvien hivenaineiden pitoisuudet ovat yleensä merkittävästi suurempia kuin heinäkasvien, joten lisättäessä puna-apilan osuutta nurmissa rehun hivenainepitoisuus lisääntyy. Karkearehun hivenainepitoisuuteen vaikuttaa kasvilajikoostumuksen lisäksi korjuuajankohta, sillä hivenaineiden pitoisuus kasvissa vähenee merkittävästi kukinnan jälkeen. Tästä johtuen nurmirehun hivenainekoostumuksessa esiintyy kirjallisuudessa suuria vaihteluita.

Kasvihuonekokeessa mineraalitypen korvaaminen lietelannan typellä ei vähentänyt minkään kasvilajin siemensadon määrää. Siementen hivenainepitoisuuksissa ( $\mathrm{Fe}, \mathrm{Zn}, \mathrm{Cu}, \mathrm{Mn})$ ei havaittu tilastollisesti merkitseviä eroja. Lietelannan orgaaniseen aineeseen sitoutuneen seleenin käyttökelpoisuus kasveille oli sen sijaan alhainen.

Tulosten perusteella pohditaan miten tuotannon kestävä tehostaminen, erityisesti kotoperäisen valkuaisen käytön lisääminen ja väkilannoitetypen korvaaminen lietteellä, vaikuttaa rehujen hivenainepitoisuuteen ja sitä kautta ravitsemukselliseen laatuun.

Asiasanat: hivenravinteet, kestävyys, tehostaminen, ravinnekierto 


\section{Johdanto}

Kestävällä tehostamisella (sustainable intensification) tarkoitetaan muun muassa kaikkia niitä keinoja, joilla voidaan lisätä ravinteiden käytön tehokkuutta ja ravinteiden kierrätystä ilman, että satotasot laskevat (Garnett ym. 2013). Viljelykasvien sadonmuodostusta eniten rajoittava kasviravinne on typpi, ja siten suuri osa kestävän tehostamisen keinoista kohdistuu typen kierrätykseen tilalla, väkilannoitetypen käytön vähentämiseen, palkokasvien suosimiseen viljelykierrossa sekä valkuaisomavaraisuuden lisäämiseen tuotantoeläinten ruokinnassa. Siitä, miten lannoituskäytänteiden tai rehukasvivalikoiman muuttuminen vaikuttaa rehujen ja elintarvikkeiden hivenainepitoisuuksiin ja sitä kautta niiden ravitsemukselliseen laatuun, ei ole juurikaan tutkimustuloksia.

Mikrokivennäisaineita eli hivenaineita tarvitaan rehuannoksessa vähemmän kuin $100 \mathrm{mg} / \mathrm{kg}$ kuiva-ainetta. Vaikka määrät ovat pieniä, ovat hivenaineet välttämättömiä monissa fysiologisissa ja biokemiallisissa tehtävissä eläinten kudoksissa. Eläimen hivenainetarpeen määrittäminen ei ole helppoa tarvemäärän pienuuden vuoksi. Lisää vaikeutta käyttösuositusten tekoon tuo eläinlajien ja yksilöiden väliset erot reagoinnissa hivenaineen saantiin, erot eri rehujen ja käyttömuotojen (epäorgaaninen vs orgaaninen) hivenaineiden imeytymisessä ja hyväksikäytössä, hivenaineiden väliset yhdysvaikutukset, hivenaineiden ja muiden ravintoaineiden yhdysvaikutukset ja hivenaineiden sisäinen kierto eläimessä. Tarpeen määrittely yksiselitteisesti eläimen tuotantotulos-, terveys- ja hedelmällisyysvaikutusten perusteella on hyvin monimutkaista, kun samalla on otettava huomioon vaikutukset eläinperäisten elintarvikkeiden hivenainepitoisuuksiin. Kotieläinten hivenainetarvetta ei tutkita aktiivisesti. Tutkimukset ovat keskittyneet yksittäisiin hivenaineisiin kuten esimerkiksi seleeniin ja rautaan. Hivenainesuositukset perustuvat varsin vanhoihin tutkimuksiin eikä niitä juurikaan päivitetä edes kansainvälisesti.

Suomalaisissa nautojen ruokintasuosituksissa hivenaineista on mukana rauta, kupari, sinkki, mangaani, jodi, koboltti, seleeni ja molybdeeni (Luke 2015). Sikojen ja siipikarjan suosituksissa ei ole kobolttia ja molybdeenia eikä sioilla myöskään mangaania. Myös hivenaineiden mahdolliset toksiset vaikutukset on otettava ruokinnassa huomioon erityisesti silloin, jos tarpeen ja haitallisen määrän ero on pieni. Hivenaineille on kirjallisuudessa esitetty eläinlajikohtaisia maksimisietorajoja, jotka ilmaisevat mihin määrään asti eläimen tiedetään sietävä hivenainetta ilman selkeitä haittavaikutuksia (NRC 2005). Tämä määrä voi olla moninkertainen verrattuna eläimen hivenaineen tarpeeseen, ruokintasuositukseen (sisältää varmuusvaran) tai EU:n määrittelemään hivenaineen enimmäispitoisuuteen koko rehuannoksessa. Erityisesti sikojen ruokinnan suunnittelussa ei yleensä huomioida perusrehusta saatavia hivenaineita, vaan hivenainetarpeet katetaan tiivisteistä tai hivenaineseoksista. Perusrehujen hivenainepitoisuuksien parempi huomioiminen ruokinnassa voisi todennäköisesti alentaa ruokinnan kustannuksia. Myös ruokinnan muutokset kuten kotimaisten palkoviljojen enenevä käyttö, voivat muuttaa hivenaineiden saantia perusrehuista.

Tässä tutkimuksessa selvitettiin miten väkilannoitetypen osittainen korvaaminen lietelannan typellä vaikuttaa siemensatokasvien hivenainepitoisuuksiin sekä miten tuontivalkuaisrehujen korvaaminen kotimaisilla palkoviljojen siemenillä ja nurmiheinäkasvien korvaaminen nurmipalkokasveilla vaikuttaa tuotantoeläinten hivenaineiden saantiin.

\section{Aineisto ja menetelmät}

Kasvihuonekoetta varten kerättiin Viikin pellolta maata (karkea hieta), joka joko jätettiin lannoittamatta (Eilannoitettu), lannoitettiin mineraalilannoitteella (Yara Mila NK2) (N $100 \%$ ) tai typestä $50 \%$ korvattiin sianlietteen typellä (sianliete + N $50 \%$ ). Koekasveina olivat härkäpapu, sinilupiini ja vehnä, joita kasvatettiin siemensadon muodostumiseen saakka $\left(18 / 15^{\circ} \mathrm{C}, 16 \mathrm{~h}\right.$ päivänpituus). Siementen kuiva-ainesato ja makrokivennäisaineiden sekä hivenaineiden pitoisuudet määritettiin $(n=4)$.

Nurmikasvilajin vaikutus (heinä:puna-apila-suhde 100:0, 70:30, 40:60 ja 10:90) rehun hivenainepitoisuuteen laskettiin käyttämällä kirjallisuudesta kerättyjä heinien ja apiloiden keskimääräisiä hivenainepitoisuuksia. Lisäksi kerättiin tietoa muiden rehujen hivenainepitoisuuksista ja nautojen hivenainesuositukista eri rehuar- 
vojärjestelmissä (GfE 2001, NRC 2001, INRA 2007, NorFor 2011, Luke 2015). Ruokintaan liittyen tehtiin eri eläinlajeille laskelmia, joissa arvioitiin malliruokintojen avulla eläinten hivenaineiden saannin muutoksia suhteessa kotimaisiin suosituksiin sisällytettäessä palkokasveja ruokintaan.

Yksimahaisten eläinten hivenaineselvityksessä optimoitiin lihasikojen, munivien kanojen ja broilereiden mallidieettejä, joissa valkuaisen lähteenä korvattiin soijarouhetta herneellä, härkäpavulla, lupiinilla tai näiden yhdistelmillä (Holopainen 2014). Lihasioilla ja munivilla kanoilla soijarouhe korvattiin kokonaan, kun taas broilereilla siitä korvattiin yli $60 \%$. Rehuja täydennettiin puhtailla aminohapoilla ja kivennäisraaka-aineilla paitsi hivenaineilla. Ravintoaineiden pitoisuudet olivat ruokintasuositusten mukaiset (Luke 2015). Tutkimuksessa verrattiin soijapohjaisen ruokinnan hivenainepitoisuuksia palkoviljoja sisältäviin ruokintoihin.

Lypsylehmien ruokintalaskelmissa käytettiin kesiarvotietojen lisäksi kirjallisuudessa esiintyviä rehujen hivenaineiden minimi- ja maksimipitoisuuksia. Tavoitteena oli arvioida hivenainetäydennyksen tarvetta suhteessa rehukasveista saataviin teoreettisiin hivenaineiden minimi- tai maksimimääriin. Lypsylehmän kontrollirehuannos perustui laskelmissa nurmisäilörehuun, ohraan, kauraa ja rypsirouheeseen väkirehuosuuden ollessa $45 \%$ ja väkirehun raakavalkuaispitoisuuden $200 \mathrm{~g} / \mathrm{kg}$ kuiva-ainetta (ka). Vertailuruokinnoissa puolet nurmikasvisäilörehusta korvattiin puna-apilasäilörehulla, ja rypsirouheen valkuaismäärä korvattiin kokonaan joko herneen, härkäpavun tai sinilupiinin siemenillä. Lypsylehmien malliruokintoja varten kerättiin kirjallisuudesta nurmisäilörehun hivenainepitoisuuksia. Pitoisuuksien keskiarvojen ja vaihteluvälin määrittelyssä käytettiin apuna maatilanäytteiden tuloksia (Valio, Artturinäytteet, L. Nyholm), jotta arvot vastaisivat kotimaisia rehuja. Väkirehukomponenttien keskiarvoina käytettiin rehutaulukkoarvojen keskiarvoja (INRA 2007, CVB 2007, Luke 2015). Minimi- ja maksiarvojen määrittelyssä käytettiin myös muita kirjallisuuden arvoja.

\section{Tulokset ja tulosten tarkastelu}

\section{Palkokasvien hivenainepitoisuudet}

Nurmikasvien sadonmuodostukselle kriittiset hivenainepitoisuudet ovat kirjallisuuden perusteella pienempiä kuin naudoille asetetut ruokintasuositukset. Raudan osalta timoteille ja nurminadalle esitetty kriittinen pitoisuus on 45 - $59 \mathrm{mg} \mathrm{Fe} / \mathrm{kg} \mathrm{ka}$ (Whitehead 2000, Lindström 2013) ja apiloille 50 - $70 \mathrm{mg} \mathrm{Fe} / \mathrm{kg}$ ka (Lindström 2013). Vastaavat arvot Zn:lle olivat heinäkasveille $10-25$ ja apiloilla $12-30 \mathrm{mg} \mathrm{Zn/kg} \mathrm{ka.} \mathrm{Nurmirehun} \mathrm{hiven-}$ ainepitoisuuksissa esiintyy kirjallisuudessa huomattavaa vaihtelua, sillä pitoisuuteen vaikuttaa merkittävästi mm. kasvin kehitysaste. Pitoisuudet ovat suurimmillaan ennen kukintaa ja vähenevät hivenravinteesta riippuen jopa kolmanneksella kukinnan jälkeen (Markovic ym. 2009). Lehtien hivenainepitoisuudet ovat lisäksi suurempia kuin varsien, joten lehtifraktion osuus sadossa vaikuttaa rehun pitoisuuksiin. Kehitysvaihe vaikuttaa erityisesti Fe- ja Zn- pitoisuuksiin, mutta ei esimerkiksi Cu- ja Mn- pitoisuuksiin (Markovic ym. 2009). Apiloiden Fe- ja Zn-pitoisuudet ovat keskimäärin suurempia kuin nurmiheinien. Esimerkiksi timotein ja nurminadan Fe-pitoisuudet vaihtelevat $57-70 \mathrm{mg} \mathrm{Fe} / \mathrm{kg}$ ka ja Zn-pitoisuudet 20-26 mg Zn/kg ka, kun vastaavat luvut apiloilla ovat keskimäärin 97-100 mg Fe/kg ka ja 26-30 mg Zn/kg ka (Lindström ym. 2012b, Hyrkäs ja Virkajärvi 2012, MTT 2013). Myös Ylärannan ja Sillanpään (1984) kenttäkokeissa puna-apilan versojen Zn-pitoisuudet olivat keskimäärin $50 \mathrm{mg} / \mathrm{kg}$, kun timotein versojen pitoisuus oli $30 \mathrm{mg} / \mathrm{kg}$, kun taas molempien kasviaineisten Fe-pitoisuudet olivat keskimäärin $100 \mathrm{mg} / \mathrm{kg}$. Tässä tutkimuksessa laskettiin paljonko tuotannon kestävä tehostaminen ja sitä kautta heinävaltaisesta apilavaltaiseen säilörehuun siirtyminen vaikuttaa nurmirehun hivenainepitoisuuksiin. Nurmirehun lajikoostumuksen muutoksella oli eniten vaikutusta rehun $\mathrm{Cu}$ - ja $\mathrm{Fe}$-pitoisuuksiin. Kun puhtaassa timotei-nurminatarehussa laskennalliset pitoisuudet olivat $3,8 \mathrm{mg} \mathrm{Cu} / \mathrm{kg} \mathrm{ka}$ ja $38 \mathrm{mg} \mathrm{Fe} / \mathrm{kg} \mathrm{ka}$, olivat pitoisuudet puna-apilavaltaisessa rehussa (60\% apilaa) 6,5 $\mathrm{mg}$ $\mathrm{Cu} / \mathrm{kg} \mathrm{ka} \mathrm{ja} 55 \mathrm{mg} \mathrm{Fe} / \mathrm{kg} \mathrm{ka}$.

Tutkimuksessa selvitettiin lisäksi miten kasvintuotannon kestävä tehostaminen ja mineraalilannoitteiden käytön vähentäminen vaikuttaa vehnän, härkäpavun ja sinilupiinin siementen hivenainepitoisuuksiin, joista tässä raportissa käsitellään sinkkiä, rautaa ja seleeniä. Kokeessa käytetty mineraalilannoite sisälsi seleeniä ja sinkkiä, mutta ei rautaa. Kasvihuonekokeessa mineraalilannoitteiden osittainen korvaaminen sianlietteellä tai kasvilaji eivät vaikuttaneet siementen Fe tai Zn-pitoisuuksiin osalta (kuvat 1a, 1b). Sekä mineraalilannoite 
(N100 \%) että liete (liete+N50 \%) lisäsivät siementen pitoisuuksia saman verran (kuva 1b). Sianlietteen käyttö lannoitteena näkyi sen sijaan siementen Se-pitoisuuksissa. Esimerkiksi vehnän siementen Se-pitoisuus väheni 0,34 :sta $0,11 \mu \mathrm{g} / \mathrm{g} \mathrm{ka}$, kun $50 \%$ mineraalilannoitteesta korvattiin sianlietteellä. Pitoisuuden väheneminen oli vastaavan suuruista myös härkäpavun ja sinilupiinin siemenissä.

Säilörehuksi korjatulla nurminata-koiranheinänurmella tehdyissä laajoissa kenttäkokeissa todettiin yhdenmukaisesti nyt saatujen tulosten kanssa, että typpilannoituksen lisäys 0 :sta tasolle $3 \times 150 \mathrm{~kg} / \mathrm{ha}$ vuodessa johti nurmen Zn-pitoisuuden tilastollisesti merkitsevään lisääntymiseen 30:sta 39 mg:aan/kg (Rinne ym. 1974). Myös Cu-pitoisuus lisääntyi 10:stä $12 \mathrm{mg}: \mathrm{aan} / \mathrm{kg}$. Sen sijaan toisin kuin tässä tutkimuksessa Rinne ym. (1974) havaitsivat typpilannoitetuissa koejäsenissä pienempiä Fe- ja Mn-pitoisuuksia kuin lannoittamattomissa koejäsenissä.

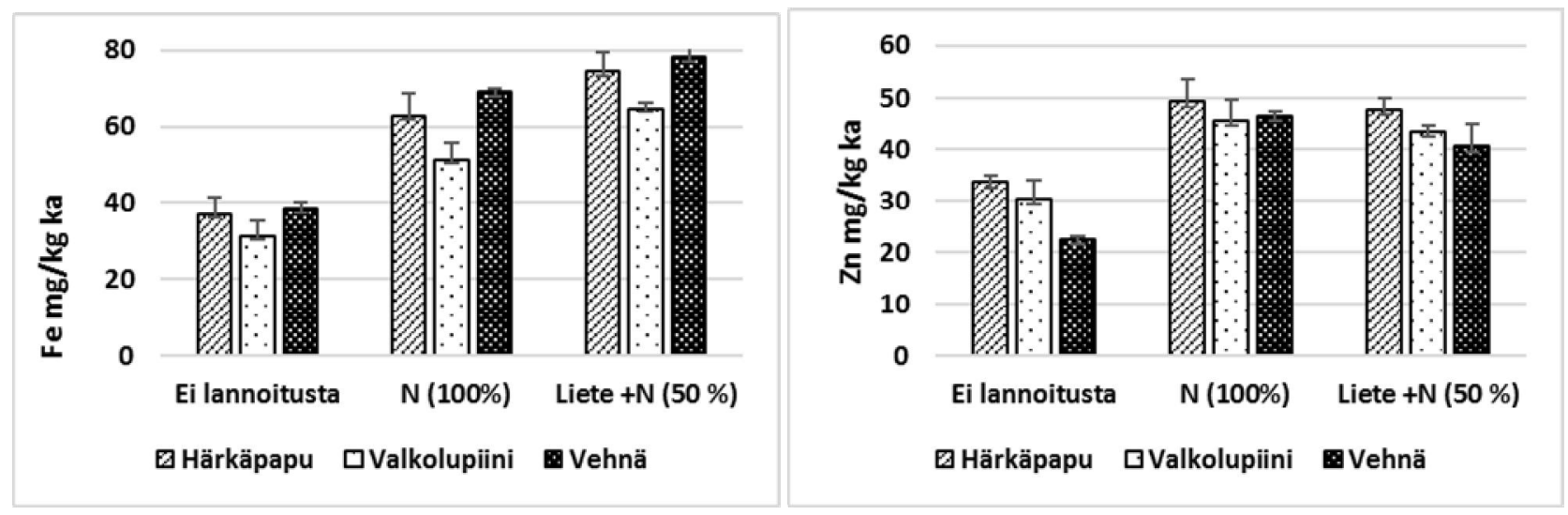

Kuva 1. Härkäpavun, valkolupiinin ja vehnän siementen a) Fe-pitoisuus ja b) Zn-pitoisuus, kun lannoitusta ei käytetä (Ei lannoitusta), kaikki N annetaan mineraalilannoitteena (N $100 \%)$ tai korvattaessa $50 \%$ lannoitetypestä sianlietteen sisältämällä typellä (Liete + N $50 \%$ ).

\section{Yksimahaisten eläinten ruokinta}

Soijan korvaaminen kotimaisilla palkoviljoilla sikojen ja siipikarjan ruokinnassa muuttaa vain vähän hivenaineiden saanteja. Eniten muuttuu lihasikojen ja siipikarjan raudan saanti, joka vähenee, jos soijasta siirrytään herne-, härkäpapu- tai lupiinipohjaiseen ruokintaan (kuva 2). Soijarouheen raudan käyttökelpoisuus sioilla on vain $38 \%$ (Bieh ym. 1997) ja palkokasvien raudan käyttökelpoisuudesta ei ole tutkimustietoa. Myös raudan erilaisten kemiallisten muotojen käyttökelpoisuus vaihtelee. Paras se on orgaanisissa rautayhdisteissä, metioniini- ja kelaattimuodoissa (Kegley ym. 2002, Feng ym. 2007).

Muiden hivenaineiden osalta ero soija- ja palkoviljapohjaisten ruokintojen välillä oli pieni. Hivenainesaanti perusrehuista ei kattanut myöskään sikojen ja siipikarjan tarpeita (Luke 2015). Jodin kohdalla ero oli pienin. Kasviperäisten hivenaineiden käyttökelpoisuutta voidaan parantaa rehuun lisätyn fytaasin avulla, koska fytiinihappokelaattiin voi sitoutua mm. Fe-, Zn- ja Mn-ioneita (Kornegay 1996).

\section{Lypsylehmien ruokinta}

Laskelmissa käytetyt valkuaisrehujen hivenainepitoisuudet on esitetty taulukossa 1. Rypsirouheen Fe- ja Mnpitoisuudet olivat palkoviljojen siemeniä suurempia, muissa hivenaineissa ei ollut vastaavan suuruista tasoeroa. Kirjallisuudessa esiintyvien prosessoitujen sivutuoterehujen, kuten rypsirehujen, pitoisuuksiin saattavat vaikuttaa kasviperäisten tekijöiden lisäksi vaihtelevat käsittelyprosessit. 


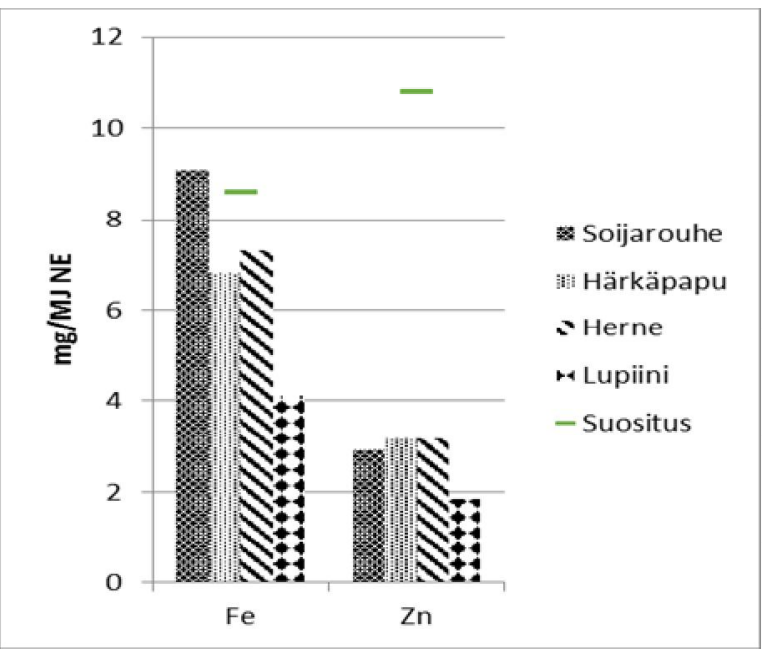

Kuva 2. Sikojen hivenravinteiden saanti (mg/MJ NE) eri ruokintamalleilla, joissa valkuaislähteenä lisätään härkäpavun, herneen ja lupiinin osuutta (Holopainen 2014). Laskenta perustuu vain perusrehuihin eli mukana ei ole erillistä hivenainetäydennystä. Tulokset on laskettu $\mathrm{mg} / \mathrm{kg} \mathrm{ka}$, jonka jälkeen arvot on muunnettu rehusuosituksissa (Luke 2015) annettuun muotoon mg/MJ NE.

Taulukossa 2 on esitetty kuuden rehuarvojärjestelmän hivenainesuositukset lypsylehmille. Mallilaskelmien ruokintojen hivenainepitoisuuksia verrattiin ensisijaisesti kotimaisiin suosituksiin, mutta samalla muiden järjestelmien vastaaviin arvoihin. Suomalaiset suositukset eroavat muista järjestelmistä erityisesti raudan ja seleenin suositusten osalta.

Palkoviljojen siementen raakavalkuaispitoisuudet ovat tyypillisesti pienempiä kuin rypsirouheen, joten rypsivalkuaisen täydellinen korvaaminen johti kilomääräisesti suurempiin palkokasvimääriin verrattuna rypsiannokseen. Tämä vaikutti osaltaan hivenaineiden saantiin. Käytettäessä keskimääräisiä hivenainepitoisuuksia heinäkasvisäilörehun osittainen korvaaminen puna-apilasäilörehulla ja palkoviljojen käyttö rypsin tilalla lisäsi ruokintojen $\mathrm{Cu}$-pitoisuutta ja vähensi Fe-, Mn- ja Se-pitoisuuksia (kuva 3). Sen sijaan vaikutus $\mathrm{Zn}$ pitoisuuteen oli vähäinen. Rehujen suuresti vaihtelevat hivenainepitoisuudet osoittavat hivenaineanalyysien tärkeyden ruokinnan suunnittelussa. Toisaalta tulosten mukaan ruokinnassa tarvitaan aina hivenainetäydennystä. Pääsääntöisesti ainoastaan kaikkien rehujen samanaikainen maksimipitoisuus riittäisi teoriassa kattamaan kotimaiset saantisuositukset.

Taulukko 1. Lypsylehmälaskelmissa käytetyt rypsirouheen ja palkokasvien siementen hivenaineiden minimija maksimipitoisuudet ( $\mathrm{mg} / \mathrm{kg}$ kuiva-ainetta).

\begin{tabular}{llllll}
\hline & \multicolumn{5}{c}{ Hivenaine } \\
\cline { 2 - 6 } Rehu & $\mathrm{Fe}$ & $\mathrm{Cu}$ & $\mathrm{Zn}$ & $\mathrm{Mn}$ & $\mathrm{Se}$ \\
\hline Rypsirouhe & $133-258$ & $4-8$ & $35-88$ & $48-70$ & 0,10 \\
Herne & $51-160$ & $7-12$ & $27-53$ & $6,0-35$ & 0,02 \\
Härkäpapu & $43-90$ & $4-21$ & $20-61$ & $4,2-20$ & 0,02 \\
Lupiini & $30-57$ & $4,3-8,2$ & $29-55$ & $5,6-57$ & 0,10 \\
\hline
\end{tabular}


Taulukko 2. Lypsylehmän hivenaineiden saantisuositukset eri rehuarvojärjestelmissä, maksimisietorajat (NRC 2015) ja EU:n antamat enimmäispitoisuudet.

\begin{tabular}{|c|c|c|c|c|c|c|c|c|c|c|}
\hline \multirow[b]{2}{*}{ Maa } & \multirow[b]{2}{*}{ Järjestelmä } & \multicolumn{8}{|c|}{ Hivenaine } & \multirow[b]{2}{*}{ Eläin } \\
\hline & & $\mathrm{Fe}$ & $\mathrm{Cu}$ & $\mathrm{Zn}$ & $\mathrm{Mn}$ & $\mathrm{I}$ & $\mathrm{Co}$ & Mo & $\mathrm{Se}$ & \\
\hline \multicolumn{11}{|c|}{ Suositus (mg/kg ka) } \\
\hline Suomi ${ }^{1}$ & Luke 2015 & 100 & 10,0 & 50,0 & $40,0^{*}$ & $0,90 * *$ & 0,10 & 0,30 & 0,10 & Lypsylehmä \\
\hline $\mathrm{USA}^{2}$ & $\mathrm{NRC}$ & 12,3 & 11,0 & 43,0 & 14,0 & 0,60 & 0,11 & - & 0,30 & Lypsylehmä, $25 \mathrm{~kg}$ maitoa/pv \\
\hline $\mathrm{USA}^{2}$ & NRC & 18,0 & 11,0 & 55,0 & 13,0 & 0,40 & 0,11 & - & 0,30 & Lypsylehmä, 54,4 kg maitoa/pv \\
\hline $\mathrm{USA}^{2}$ & NRC & 13,0 & 12,0 & 21,0 & 16,0 & 0,40 & 0,11 & - & 0,30 & Lypsylehmä, ummessa, 240 pv tiineenä \\
\hline Australia ${ }^{3}$ & $\mathrm{ARC}$ & $30-40$ & $3-27$ & $9-18$ & - & $0,15-2,0$ & - & - & 0,05 & Nautakarja \\
\hline $\mathrm{Saksa}^{4}$ & GfE & 50,0 & 10,0 & 50,0 & 50,0 & 0,50 & 0,20 & - & 0,20 & Lypsylehmä (ummessa ja lypsävä) \\
\hline Scandinavia $^{5}$ & NorFor & 50,0 & 10,0 & 50,0 & 40,0 & 1,00 & 0,10 & - & 0,20 & Lypsylehmä \\
\hline Ranska $^{6}$ & INRA & - & 10,0 & 50,0 & 50,0 & $0,2-0,8$ & 0,30 & 0,10 & 0,10 & Märehtijät \\
\hline \multicolumn{11}{|c|}{ Maksimisietoraja } \\
\hline $\mathrm{USA}^{7}$ & NRC & 500 & 40 & 500 & 2000 & 50 & 25 & $5-10$ & 5,0 & Nautakarja, mg/kg ka \\
\hline $\mathrm{EU}^{8}$ & & 500 & 15 & 150 & 150 & 5,0 & 1,0 & 2,5 & 0,50 & Lypsylehmä, mg/kg \\
\hline
\end{tabular}

${ }^{1}$ Luke (2015); ${ }^{2} \mathrm{NRC}(2001) ;{ }^{3} \mathrm{ARC}(2007) ;{ }^{4} \mathrm{GfE}(2001) ;{ }^{5}$ Nielsen \& Volden (2011); ${ }^{6}$ Meschy $(2007) ;{ }^{7} \mathrm{NRC}(2005)$;

${ }^{8} \mathrm{EU}$ : hivenaineen maksimipitoisuus $\mathrm{mg} / \mathrm{kg}$ koko rehuannoksessa, jonka kosteuspitoisuus $12 \%$

*Kolmen ensimmäisen laktaatiokuukauden aikana $80 \mathrm{mg} / \mathrm{kg} \mathrm{ka}$; ** Goitrogeeneja sisältävillä rehuilla 1,3, 1,2 ja 2,0

$\mathrm{mg} / \mathrm{kg} \mathrm{ka}$

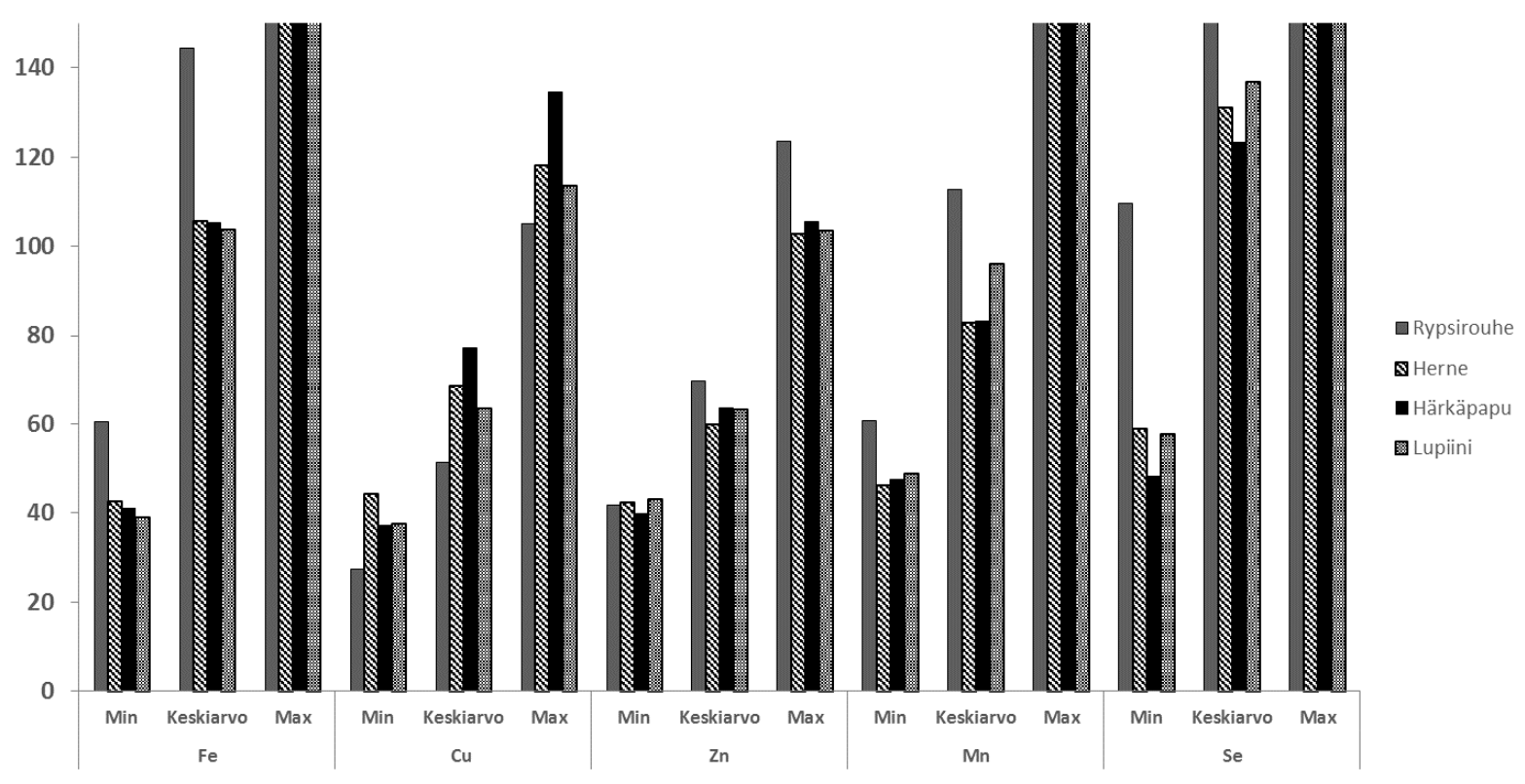

Kuva 3. Esimerkkilaskelma lypsylehmän rehuannoksen Cu-, Zn-, Mn- ja Se-pitoisuuksista ilmaistuna prosenttiosuutena suosituksesta (Luke 2015). Kontrolliruokinta koostui rypsirouheesta, viljasta ja nurmisäilörehusta. Vertailuruokinnoissa rypsirouhe korvattiin herneellä, härkäpavulla tai sinilupiinilla ja puolet nurmisäilörehusta korvattiin puna-apilasäilörehulla. Rehujen hivenainepitoisuutena käytettiin kaikille rehuannoksen rehuille kirjallisuudessa esiintyviä mini- tai maksimiarvoja tai eri maiden rehutaulukkoarvojen keskiarvoja. Ruokinnassa ei ole mukana hivenainelisiä. 


\section{Johtopäätökset}

Kasvilaji vaikuttaa rehuannoksen hivenainepitoisuuteen. Sen sijaan väkilannoitetypen osittainen korvaaminen sian lietteen typellä ei vaikuttanut merkittävästi härkäpavun, valkolupiinin tai vehnän hivenainepitoisuuksiin. Soijan korvaaminen kotimaisilla valkuaislähteillä kuten herneellä ja härkäpavulla, vähentää sikojen ja siipikarjan raudan saantia. Vaikutus muiden hivenaineiden saantiin on melko vähäinen. Apilan osuuden lisääntyminen säilörehunurmissa lisää märehtijöiden ruokinnassa useiden hivenaineiden saantia. Jos lypsylehmän ruokinnassa korvataan säilörehumuutoksen lisäksi rypsi kokonaan palkoviljojen siemenillä, vaihtelee vaikutus hivenaineesta toiseen. Kaiken kaikkiaan voidaan todeta, että hivenaineiden saanti perusrehuista ei pääsääntöisesti kattanut sikojen, siipikarjan ja lypsylehmien voimassa olevia kotimaisia saantisuosituksia. Eri maiden hivenaineiden saantisuositusten vertailu puolestaan osoitti, että kotimaisten hivenainesuositusten tarkistaminen on tarpeen.

\section{Kirjallisuus}

ARC (Agricultural Research Council) 2007. Nutrient requirements of domesticated cattle. Csiro publishing.

European Union Register of Feed Additives 2015. Edition 222, released 09.12.2015. http://ec.europa.eu/food/food/animalnutrition/feedadditives/registeradditives_en.htm

Garnett, T., Appleby, M.C., Balmford, A., Bateman, I.J., Benton, T.G., Bloomer, P., Burlingame, B., Dawkins, M., Dolan, L., Fraser, D., Herrero, M., Hoffmann, I., Smith, P., Thornton, P.K., Toulmin, C., Vermeulen, S.J. \& Godfray, H.C.J. 2013. Sustainable intensification in agriculture: premises and policies. Science 341:33-35.

GfE (Gesellschaft für Ernährungsphysiologie) 2001. Recommendations for the supply of energy and nutrients to the dairy cows and beef cattle (Empfehlungen zur Energie- und Nährstoffversorgung der Milchkühe und Aufzuchtrinder). Publisher: DLG e.V.

Holopainen 2014. Valkuaislähteen vaikutus kotieläinten hivenaineiden saantiin. Maisteritutkielma. Maataloustieteiden laitos, Helsingin yliopisto. $66 \mathrm{~s}$.

Hyrkäs, M. \& Virkajärvi, P. 2012. Nurmen kasvu- ja kehitysprosessit. Maatalouden tutkimuskeskus, raportti 56. Jokioinen:MTT. $121 \mathrm{~s}$.

Kegley, E.B., Spears, J.W., Flowers, W.L. \& Schoenherr, W.D. 2002. Iron methionine as a source of iron for neonatal pig. Nutrition Research 22: 1209-1217.

Kornegay, E.T. 1996. Nutritional, environmental and economical considerations for using phytase in pig and poultry diets. International Symposium on Nutrient Management of Food Animals to Enhance the Environment. ss. 276-304.

Lindström, B.E.M. 2013. Micronutrients in temperate forage crops grown in Sweden. Doctoral Thesis No. 2013:03. Acta Universitatis Agriculturae Sueciae. Swedish University of Agricultural Sciences, Department of Crop Production Ecology. $58 \mathrm{~s}$

Lindström, B.E.M., Frankow-Lindberg, B.E., Dahlin, A.S., Wivstad, M. \& Watson, C.A. 2013. Micronutrient concentrations in common and novel forage species and varieties grown on two contrasting soils. Grass and Forage Science 68:427-436.

Luke (Luonnonvarakeskus) 2015. Rehutaulukot ja ruokintasuositukset. Luonnonvara- ja biotalouden tutkimus 40/2015. $58 \mathrm{~s}$.

Markovic, J., Strbanovic, R., Cvetkovic, M., Anelkovic, B. \& Zivkovic, B. 2009. Effects of growth stage on the mineral concentrations in alfalfa (Medicago sativa L.) leaf, stem and the whole plant. Biotechnology in Animal Husbandry 25: 1225-1231.

Meschy, F. 2007. Alimentation minérale et vitaminique des ruminants: actualisation des connaissances. INRA Productions.

MTT 2013. Rehutaulukot ja ruokintasuositukset (verkkojulkaisu). Jokioinen: MTT Maa- ja

elintarviketalouden tutkimuskeskus. Viitattu 5.3.2014. Saatavissa: http://www.mtt.fi/rehutaulukot

Nielsen, N. I., \& Volden, H. 2011. Animal requirements and recommendations. In: NorFor-The Nordic feed evaluation system.

NRCti(ONatiAnaHdResearcB66@700il) 2001. Nutrient Requirements of Dairy Cattle, 7th revised edition. Na- 
NRC (National Research Council) 2005. Mineral tolerances of animals, second revised edition. National Academy Press. ss.14-15.

Whitehead, D.C. 2000. Nutrient elements in grassland: soil-plant-animal relationship. 1 painos. Wallingford, UK: CABI Pubcations. $369 \mathrm{~s}$.

Rinne, S.-L., Sillanpää, M., Huokuna, E. \& Hiivola, S.-L. 1974. Effects of heavy nitrogen fertilization on iron, manganese, sodium, zinc, copper, strontium, molybdenum and cobalt contents in ley grasses. Annales Agriculturae Fenniae 13: 109-118.

Yläranta, T. \& Sillanpää, M. 1984. Micronutrient contents of different plant species grown side by side. Annales Agriculturae Fenniae 23: 158-170. 